\title{
A possible general mechanism of the signal transfer switching on the $\alpha / \beta$-interferons expression. 2. The role of the cAMP in the process of the interferon induction
}

\author{
Alexander V. Karpov \\ Danylo Zabolotnoho Institute of Microbiology and Virology, National Academy of Sciences of Ukraine \\ 154 Zaboiotny str., Kyiv, 252143 , Ukraine
}

The author carries out an analysis of available data concerning the participation of cycli: adenosine $3^{\prime}, 5^{\prime}$-monophosphate (cAMP) in the signal transduction pathway on the $\alpha / \beta$-interferons (IFN) expression during the induction process. The cAMP is known to participatio in the activation of protein kinases during the interferon induction as well as of nuclear factors activating specifically the regulating domains of IFN genes. The CAMP is thought to be a secondary key messenger mediating the signal for $\alpha / \beta-I F / v$ intuction, the first stage of this induction being the local cell membrane deformation caused by diffirent indiscers.

The regulation of the interferon (IFN) genes expression as well as the expression of a lot of other ones is usually realized by the induction mecharism, i. e. by the extracellular activation [1]. The IFN induction is now known to be realized both by viruses and by many compounds of high and low molecular weight $[1-4]$. The induction process is thought to be a multi-stage and perhaps a branched one beginning from any inductor interaction with the cell surface and completing by the initiation of the IFN genes transcription. It must be noted that no generally accented up-to-date conception has been elaborated concerning the IFN induction mechanism as well the nature of intermediate signal carriers assuring the IFN-ccding genes activation following the action of multilateral inducers.

A great body of experimental data accumulated during several last years shows the genes coding both and $\alpha$ - and $\beta$-IFN to contain multiple positive and negative cis-acting elements necessary for induction. These elements are mostly able to bind with different protein factors also influencing the transcription $[5$,

(C) A. V. KARPOV, 1999
$6 \%$ It is also noteworthy the activation of both $c$ - and $\beta$-IFN genes needs no new protein synthesis. So it is clear the cell to possess some «latent» («silent») factors necessary for the effective IFN genes expression, these factors being activated by the induction process $[6,7]$.

I have earlier proposed a hypothesis postulating the first $\alpha$ - and $\beta$-IFN induction stage to bc: a rather common phenomenon - the local cellular menbrane deformation taking, place as a result of any IFNinducing agent action 181 . In this paper I would like to discuss some possible events on the level of molecular processes developing after such menbrane deformation.

The interaction of some biologically active substances with the cellular membrane as well as some other processes cause the activation of many enzymes including also adenylate cyclase - an enzyme responsible for the cyclic adenosine- $3^{\prime}, 5^{\prime}$-monophosphate (cAMP) synthesis. Due to such activation the intracellular cAMP level increases [9]. A similar phenomenon is also found following local artificial ruechanical effect on the cell membrane $[10-12]$. The cAMP is known to belong 10 a group of so-called «secondary messengers» - ubiquitous intracellular 
substances activating a lot of genes [13], hormones [14], and also protein factors regulating the expression of many genes [15]. The transcription initiation is realized due to the activation of a specific CAMP-dependent protein kinase - protein kinase A (PKA) activating a corresponding transcription factor [16] by a phosphorylation process. The inactive PKA holoenzyme consists of two regulatory subunits possessing two cAMP-binding sites and two catalytic ones. There are two types of regulatory subunits, the catalytic ones being identical. The binding of four cAMP molecules to regulatory subunits causes the release of catalytic monomer subunits phosphorylating cell proteins.

The participation of different protein kinases including also the cAMP-dependent one in the IFN induction process is known for a rather long time [17]. Two inter-independent types of transductive IFN-activating signals are now thought to be set in motion following extracellular stimulus. Protein kinases are found to participate directly in the signal development of both types. The first IFN-activating process needs the $\mathrm{Ca}^{2+}$-calmodulin system participation, the second one includes the activity of the $\mathrm{Ca}^{2}$-dependent diacylglycerol protein kinase $\mathrm{C}$ [18]. Some experiments with different inhibitors of this enzyme have shown the poly (I)-poly (C)-induced IFN synthesis, contrary to the virus-induced one, is dependent on this enzyme activity [19]. The inhibition of the dsRNA- and virus-induced $\beta$-IFN synthesis by 2 -aminopurine proves the role of the dsRNA-clependent protein kinase in the $\beta$-IFN induction. This anomalous nucleoside is found to be a potential nhibitor of some protein kinases including also dsRNA-dependent and heme-regulated protein kinase eIF.-2 [20, 21]. The data given above confirm the importance and significance of this type enzymes in he IFN induction. The cAMP participation in this process, except its direct role in the PKA activation discussed above, includes also several stages of the protein kinases mediated signal transfer which is jmpossible without the cAMP. For example, this secondary messenger has been demonstrated to st. rnulate the PKC penetration into the nucleus [22]. At the same time the cAMP increases the activity of ionic channels permitting $\mathrm{Ca}^{2+}$-ions introduction into the cell followed by the PKC activation [23]. In its turn, this process is also known to be negatively regulated, an adenylate cyclase subunit being inactivated by the PKC [24] and the intracellular $\mathrm{Ca}^{2+}$-excess leading the cAMP-splitting phosphodiesterase activation [25]. The addition of the PKA activating cAMP analogs decreases the cAMP level in hepatocytes [26]. All these data suggest the existence of numerous negative feed back regulation pathways in the system of secondary messengers; the negative regulation is thought to prevent the excessive cell stimulation. I think such regulation is to play the determinative crucial role for the choice of any signal transduction pathway necessary for the IFN induction in any concrete case of interactions between any IFN inducer and the cell. My conception correlates completely with the conclusion concerning any concrete case of the secondary messengers participation in the IFN synthesis foliowed by viral and non-viral IFN induction [19].

To discuss the cAMP role at the final stages of the IFN genes expression, it is necessary to remember some experimental results. PRDIV, one of the four positive $\beta$-IFN regulatory elements, contains a site binding transcription factors of the ATF/CREB family [27-29], the CPEB factor assuring the cAMP-dependent induction [30]. The multiple PRDIV copies have been also demonstrated to realize both virus- and cAMP-dependent IFN induction with heterologous promoters [29].

At the same time the cAMP has been shown to participate in the virus-directed IFN gene induction which is dependent on PRDII, another positive regulating domain of this gene promoter [31]. Such induction is usually realized with the help of a specific nuclear protein $-N F-\kappa B$. This protein has been shown to bind the $\kappa \mathrm{B}$-site of the $\kappa$-chain $(\mathrm{NF}-\kappa \mathrm{B})$ in the immunoglobulin enhancer $[32,33]$. The NF- $k$ B is demonstrated to be present in the cytoplasm of many cells forming a complex with an inhibitor protein, $I \kappa \mathrm{B}$ [34]. The cell treatment by several agents, such as phorbol ethers, lypopolysaccharides, and cAMP, the last case being especially noteworthy, causes the dissociation of the $\mathrm{NF}-\kappa \mathrm{B} / \mathrm{I} \kappa \mathrm{B}$ complex and the development of a nuclear NF- $\kappa$ B-binding activity [35]. Besides, some in vitro experiments suggest the activation of a NF- $\kappa \mathrm{B}$ precursor followed by its conversion into an active DNA-binding form is realized with the participation both of the PKC and the cAMP dependent PKA [36].

The NF- $\kappa \mathrm{B}$ is found to bind specifically tho PRDII site of the $\beta$-IFN promoter, the PRDII mutations decreasing the virus-directed IFN induction in vivo reduce also the NF- $\mathrm{B}$ affinity to the PRDII in vitro $[37,38]$. It is noteworthy the $\mathrm{NF}-\kappa \mathrm{B}$ binding and its transfer to the nucleus are activated both hy viruses and by poly $(\mathrm{I})-\operatorname{poly}(\mathrm{C})$ preparations [31, $37-39$ ]. The $N F-\kappa B$ is also known to activate the PKC and the heme-regulated kinase eIF-2 as well as the cAMP-dependent PKA. At the same time, the $I k \mathrm{~B}$ is demonstrated to become phosphorylated and inactivated in the presence of the PKC and of the elF-kinase, but not in the presence of the PKA [35]. 
All these data including especially the very fact of the cAMP-mediated $\alpha / \beta$-IFN induction $[5]$ as well as the experiments suggesting the intracellular cAMP concentration increasing directed by the dsR NA [40] and synthetic nucleotides [41 [ prove the cAMP being the secondary messenger to make the principal contribution into the developing of several signal transfer pathways leading from the cellular membrane to the $\alpha / \beta$-IFN coding genes activation.

Besides, I would like to discuss a problem of the cAMP-mediated signal; I think this term to concern not only the $\alpha / \beta$-IFN expression, but also the expression of many other genes activated following the virus/dsRNAs interactions with any cell [42]. It $i$. noteworthy a similar situation is found following any mechanical deformation of the cell membrane [11, 12]. Unfortunately, the data concerning this last case have been never discussed in connection with the IFN induction.

At the same time, any similar cAMP-mediated signal is to be a rather specific one, the IFN induction process being found to take place following the suppression of the general cellular protein synthesis $[1-4]$. This process specificity is possible to be due to two additional ones. Firstly, the cAMP together with a lot of cAMP-dependent kinases and some other proteins is now thought to form a rather complex coordinated system of secondary messengers possessing several entries for extracellular signals and having numerous feed back factors [25]. Such system is able to adapt its possibilities for any concrete case to realize such a general cell response as the IFN induction. Secondly, some cAMP-independent factors have been also shown to regulate the INF synthesis [5]. The additive action of all these factors participating in the IFN induction is to increase the specificity level.

During a rather long time some synthetic polynucleotides belonging to an important group of IFNinducing substances are known to be compounds stimulating the synthesis of antibodies. Such a striking property of such compounds is thought to be correlated with their ability to increase the adenylate cyclase activity in immunocompetent cells followed by the iacreased intracellular cAMP concentration [43]. The accelerated immune response has been demonstrated not only as a result of polynucleotide-induced increasing of the adenylate cyclase activity, but also as a consequence of the phosphodiesterase inhibitors effect, such as theophilline and caffeine [44]. It is clear such immune responses to be correlated with or directly due to the IFN-inducing activity. There are direct evidences that such compounds as methylxanthines (purines) and a lot of their derivatives including theophilline and caffeine mentioned above as well as theobromine, papaverine and some other ones are also cAMP phosphodiesterase inhibitors [45, 46 l possessing some marked IFN-inducing proserties [47]. At the same time I think the direct IFNinducing cytotropic effect of the cAMP is not a probable one, this compound being inable to penetrate through the cell membrane [13].

I think all these data permit to assume the cAMP to be the crucial factor participating in the IFNinducing signal transfer developed earlier according to the postulated mechanism due to the specific cell membrane deformation $[8]$. Such a situation does not exclude the synergistic contribution of some other IFN-inducing factors leading finally to the process of the genes expression coding the I type IFN (i. e. $\alpha / \beta$-IFN). So I think the further investigations concerning all the details of the IFN regulation and IFN expression mentioned above will disclose the picture of the cAMP participation in this process as well as some variations concerning this compounc concentrations at differen! IFN induction stages; these data are to be of great value and to help us to solve the general problem of the IFN induction. The experiments with many different inducers and inhibitors of the IF'N synthesis participating in the cAMP metabolism are to be especially useful.

\section{O. B. Kapno:}

Можливий універсальний механізм передачі сигналу до експресії $\alpha / \beta$-інтерферонів. 2. Роль сАМР ири індукциї

Резюме

Проаналізовано літературні дані стосовно участі циклічного аденозин-3',5'-монофосфкту (сAMP) при передачі сиг клу до експресії $x / \beta$-інтерферонік (IФН) у процесі індукцї. описано участь самР в активоції протеінкіназ, які беруть уиасть в індукцї, а також ядерних факторів, ицо специфічно активують регуляторні домени генів I\$). Висунуто припущеіня, що сАМР виступас в ролі ключового вторинного месенджера, який опосередковус сигнал до індукції $\alpha / \beta-І Ф Н$, почанковим етапом якого є' специфічна деформація клітинної ме.і́рани під дією різних індукторів.

\section{A. B. Kapnos}

Возможный универсальиый механизм передачи сигнала $x$ экспрессии $\alpha / \beta$-интерферонов. 2. Роль сАМР при индукции Резюме

Проанализированы литературные данные относителью участия цикли иеского аденозин-3',5'-монофосфапа (сАMP, при передаче синнала к экспрессии $\alpha / \beta$-интерферонов (ИФН) в процессе индукции. Описано унастие сАмР г активаяии протеинкиназ, участвующих в индукции, а такхе кдернцх ;ракторов, специфинески активирующих регуляторнье домень генов ИФН. Видвинуто преоположение о том, цто самР ви:ступает в роли кіючевогом вторичного мессенджера, опосредующе- 
sо сигнал к индукции $\alpha / \beta-И \Phi Н$, нацальнык: этапом которого пөлиется спицифическая деформация клеточной мембраны под sоздейстанем различных индукторов.

\section{REF ERENCES}

1. Ho $M$. Induction and inducers of interferon // Interferon 1 . General and applied aspects / Ed. A. Billiau.-Amsterdam; New York; Oxford: Elsevier, 1984.-P. 79.--124.

2. Marcus $P$. $I$. Interferon induclion by viruses: double-stranded ribonucleic acid as the common proximal inducer molecule // Interferon 3. Mechanisms of production and action / Ed. R. M. Friedman.-Amsterdam; New York; Oxford: Elsevier, 1984.P. $113-175$.

3. Stringfellow D. A. Induction of interferon with low molecular weight compounds // Meth. Enzymol.-1981.-78.-P. 262284

4. Torrence $P$. $T$. , De Clerca $E$. Interferon induction by nucleic acids: structure-activity relationships // Interferon and their applications / Eds P. E. Came, W. A. Carter-Berlin: Springer, 1984.-P. 371-383.

5. Marliatis T., Whittemore L. A., Du W. et al. Positive and negative control of human interferon- $\beta$ gene expression // Transcriptional regulation / Eds S. L. McKnight, K. R Yamamoto.-New York: Cold Spring Harbor Lab. press, 1992.-P. 1193-1220.

6. Taniguchi $T$. Regulation of cytokine gene expression // Annu Rev. Immunol.-1988-6.-P. 439-464

7. Goodbourn S., Maniatis T. Overlapping positive and negative regulatory domains of the human $\beta$-interieron gene // Proc. Nat. Acad. Sci. USA. - 1988. - 85.-P. 1447-1451

8. Karpov A. V. A possible genrral mechanism of the signal transfer switching on the $\alpha / \beta$-interferons expression. 1 . The local cell membrane deformation as the first induction stage // Биополимеры и клетка.-1998.-14, № 6.-С. 561-566.

9. Бужурина Н. М., Панов М. А. Механизмы формирования клеточного ответа на виешние воздействия // Обц. пробл. физ.-хим. биологии.-М.: ЗИНІИТИ, 1986.-С. 1-258 (Итоги науки и техники, Т. 3).

10. Watson $P$. A. Direct stimulation of adenylat cyclase by mechanical forces in $\mathbf{S 4 9}$ mouse lymphom a cell during hyposmotic swelling // J. Biol. Chem. $-1990,-265 .-$ P. 65696574.

11. Olsen $S$-P., Clapham D. E. Davies P. E. Haemodynamic shear stress activates a $K^{+}$current in vascular endothelial cell // Nature.-1988.-331.-P. 168-170.

12. Wang N., Butler J. P., Ingber D. E. Hechanotransduction across the cell surface and through the cytoskeleton $/ i$ Science. - 1993.-260.-P. 1124-1127.

13. Преображенская Н. П., Юркезич А. М. Современные предсгавления о роли цик.ло-АМФ как регулятора актив ности ферментов /// Вопр. мед. химии.--1973.-19, № 5.C. $451-462$.

14. Sutherland $E . W$. Studies on the mechanisin of hormone action // Science.-1972.-177.-P. 401-408.

15. Comb M., Bimberg N. C., Seascholtz A. et al A cyclic-AMP and phorbol ester-inducible DNA element i/ Nature._1986.323. - P. 353-356.

16. Gonzales G. A., Yamamoto K. K., Fischer $W . H$. et al. A cluster of phosphorylation sites on the cyclic AMP-regulated nuclear factor CREB predicted by its sequence // Ibid.1989.-337. -P. 749-752.

17. Neldolesi $M$. F. Friedman $R$. M., Kohn \& D. An interferoninduced increase in cyclic AMP levels precedes the establishment of the antiviral state // Biochem. and Biophys. Res. Communs. - 1977.-79.-P. 239-243.
18. Nishizuka $Y$. Turnover of inositol phospholipids and signal transduction // Science. - 1984.-225. - P. 1365-1370.

19. Thacore H. R., Lin H.-Y., Davis P. L., Schoenl M. Effect of protein kinase $\mathbf{C}$ inhibitors on interferon- $\beta$ production by viral and non-viral inducers // J. Gen. Virol.-1990.-71.P. 2833-2839.

20. Marcus $P$. I., Sekellick $M$. I. Interferon induction by viruses. XVI. 2-Amınopurine blocks selectively and reversibly an early stage in interferon induction // Ibid.-1988.-69.-P. 16371645 .

21. Zinn K., Keller A., Whittemore L.-A., Maniatis T. 2-Aminopurine selectively inhibits the induction of $\beta$-interferon, $c$-fos and $c$-myc gene expression // Science.-1988.-240.P. 210-213.

22. Cambier J. C., Newell M. K. Justement L. B. et a!. Ia binding ligands and cAMP stimulate nuclear translocation of $\mathrm{PKC}$ in: $\mathrm{B}$ lymphocytes // Nature.-1987.-327.-P. 629-632.

23. Cachelin A. B., de Peyer J. E., Kokubun S., Reuter II. Ca'channel modulation by 8-bromocyclic AMT in cultured heart cells // Ibid. - 1983.-304.-P. 462-464.

24. Katada T., Gilman A. G., Watanabe Y. et al. Protein kinase $C$ phosphorylates the inhibitory guanine-nucleotide-binding regl latory component and apparently suppresses its function in hormonal inhtbition of adenylat cyclase // Eur. J. Biochem.-1985. - 151.-P. 431-437.

25. Романииков Ю. М. Факторы роста, вторичные мессен джеры и онкогены // Успехи соврем. биологии.-1991.111 , № 1.-C. 19-33.

26. Corbin J. D., Beebe S. J., Blackmore P. F. cAMP-dependent protein kinase activation lowers hepatocyte cAMP // J. Eioi. Chem.-1985.-260.-P. 8731-8735

27. Hai T., Fang L., Alegretto A. et al. A family 'f immunologically related transcription factors that incluaes mutiple forms of ATF and AP-I // Genes Dev.-1988.-2,-P. 12161226.

28. Hai T., Fang L, Coukas W. J., Green M. R. Transcription factor ATF cDNA clones: An extensive family of leucine zipper proteins able to selectively form DNA-binding heterodimers // Ibid.-1989.-3.-P. 2083-2090.

29. $D u W$., Maniatis $T$. An ATF/CREB element is required for virus induction of the human interferon- $\beta$ gene // Proc. Na Acad. Sci. USA. - 1992.-89.-P. 2150-2154.

30. Liu F., Green $M$. R. A specific member of the A'TF transcrip tion factor family can mediate transcription activating by the adenovirus E la protein // Cell._1990.-61.-P. 12171224.

31. Hiscott J., Alper D., Cohen $L$ et al. Induction of human interferon gene expression is associated with a nuclear factor that interacts with the NF- $\kappa$ B site of the human immunodeficiency virus enhancer // J. Virol._1989._63.-P. 25572566 .

32. Sen $R$., Baltimore $D$. Multiple nuclear factors interac: with the immunoglobulin enhancer sequences // Cell. -1986.-46.P. 705-716.

33. Sen $R$., Baltimore $D$. Inducibility of $\kappa$ immunuglobulin eniancer-binding protein NF- $\kappa$ B by a post-translational mechanisrn // Ibid.-47.-P. 921-928.

34. Baeuerle A. S., Baltimore D. A $65 \mathrm{kD}$ subunit of active NF- $\kappa \mathrm{B}$ is required for inhibition of NF- $\kappa$ B by $I \kappa B / /$ Genes Dev.1989.-3.-P. 1689-1698.

35. Ghosh S., Baltimore D. Activation in vitro of NF-אB by phosphorylation of its inhibitor $\mathrm{I} \kappa \mathrm{B} / /$ Nature.-1990.-344. P. 678-682.

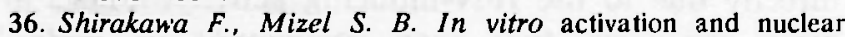
translocation of NF- $\kappa \mathrm{B}$ catalized by cyclic AMP-dependent 
protein kinase and protein kinase $\mathrm{C} / / \mathrm{Mol}$. Cell Biol.1989. -9.-P. 2424-2430.

37. Lenardo $M$. J., Fan C.-M., Maniatis T., Baltimore $D$. The involvement of NF- $\boldsymbol{x B}$ in $\beta$-interferon gene regulation reveals its role as a widely inducible mediator of signal transduction // Cell.-1989.-57.-P. 287-294.

38. Visvanathan $K \quad V$., Goodbourn $S$. Double-stranded RNA activates binding of NF- $\boldsymbol{K B}$ to an inducible element in human $\beta$-interferon promoter // EMBO J.-1989.-8.-P. $1129-$ 1138.

39. Fujita T., Kimura Y., Miyamoto $M$. et al. Induction of endogenous IFN $-\alpha$ and IFN- $\boldsymbol{\beta}$ genes by a regulatory transcription factor, IRF-I // Nature.-1989.-337.-P. 270-272.

40. Галстян Г. Г., Мхитарян Г. С., Гаспарян Н. Т. и dр. Влияние асРНК на содержание циклических нуклеотидов в различных тканях эукариот // Журн. эксперим. и клин. медицины. $-1989 .-29$, № 5.-C. $477-482$.

41. Земсков В. М. Синтетические полинуклеотиды как неспецифические стимуляторы иммунологической системы организма // Успехи соврем. биологии._1973.-76, № 1.C. 3-20.

42. Wathelet M. G., Berr P. M., Huez P. M. Regulation of gene expression by cytokines and virus in human cells lacking the type-1 interferon locus // Eur. J. Biochem.-1992,--206.P. $901-910$.

43. Winchurch R., Ishizuka $M$, Webb D., Braun $W$. Adenyl cyclase activity of spleen cells exposed to immunoerthancing synthelic oligo- and polynucleotides // J. Immunol.-1971.$106-$ - P. 1399-1402.

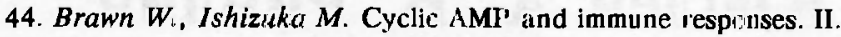
Phosphodiesterase inhibitors as potentiators of polyn:ıcleotide effects on antibody formation // Ibid-107.-P. 1036-1042.

45. Bucher $R$. W., Sutherland $E$. $W$. Adenosine $3^{\prime}, 5^{\prime}$-photiphate in biological materials. I. Purification and properties of cyclic $3^{\prime}, 5^{\prime}$-nucleotide phosphodiesterase and use of this enzyme to characlerize adenosine $3^{\prime}, 5^{\prime}$-phosphate in human uriue // J. Biol. Chem.-1962,-237. -P. 1244-1247.

46. Triner L., Vulliemaz Y., Schwartz I., Nahas C. G. Cyclic phosphodiesterase activity and the action of papaverine // Biochein, and Biophys. Res. Communs. $-1970-40 .-P .64-$ 67.

47. Григорян С. С., ПТоверенньй А. М., Ериов Ф. И. Вазодилета горы как индукторы интерферона // Вопр. вирусологии. -1987.-32, № 2.-C. 204-208.

УДК 578.245 .577 .113 .7

Received 27.11.97 